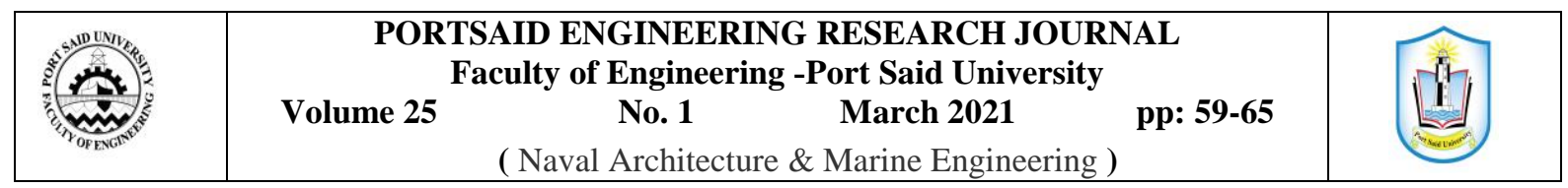

\title{
Improving Container Ship's Energy Efficiency Operational Indicator (EEOI) by Speed Management
}

\author{
W. Yehia', L. B. Kamar ${ }^{2}$, H. I. Mosaad ${ }^{3}$, and M. M. Moustafa ${ }^{4}$ \\ Received: 2 September 2020; Accepted: 9 October 2020
}

\begin{abstract}
Nowadays, ship's energy efficiency plays a key function in reducing fuel consumption and safety of the maritime environment. EEOI is an energy efficiency monitoring indicator for existing ships. This research aimed to enhance the container ships' energy efficiency and environmental sustainability by speed management during ship operation. Speed management strategy as an energy efficiency improving measure, could make more sense while applied on container ships due to the higher speeds of this ship type. This paper also outlines the calculation procedures for ship-based GHG emissions. In this paper, a 700 TEU container ship has been selected as a test case. Actual statistical operational data of the candidate vessel have been reviewed for three consecutive years and specifically analyzed to examine the impact of reduced speed on EEOI, consequently on ship's emissions, and fuel consumption. This study showed enthusiastic outcomes relating to emissions reduction and EEOI improving as well.
\end{abstract}

Keywords: Energy Efficiency, EEOI, Speed Management, Fuel Consumption, GHG Emissions.

\section{Abbreviations and Symbols}

\begin{tabular}{|c|c|}
\hline GHG & Green House Gas \\
\hline EEDI & Energy Efficiency Design Index; \\
\hline EEOI & Energy Efficiency Operational Indicator; \\
\hline IMO & International Maritime Organization; \\
\hline MBM & Market Based Measure; \\
\hline MEPC & $\begin{array}{l}\text { Marine Environment } \\
\text { Committee; }\end{array}$ \\
\hline TEU & Twenty-foot Equivalent Unit; \\
\hline $\mathrm{C}_{\mathrm{F}}$ & $\mathrm{CO}_{2}$ conversion factor; \\
\hline $\mathrm{CF}_{\mathrm{j}}$ & $\begin{array}{l}\text { The fuel mass to } \mathrm{CO}_{2} \text { mass conversion } \\
\text { factor for fuel } \mathrm{j} \text {; }\end{array}$ \\
\hline $\mathrm{CO}_{2}$ & Carbon dioxide; \\
\hline D & $\begin{array}{l}\text { Distance in nautical miles corresponding } \\
\text { to the cargo carried or work done; }\end{array}$ \\
\hline EME & $\begin{array}{l}\text { The certified } \mathrm{NO}_{\mathrm{x}} \text { emissions per } \mathrm{KWh} \text { for } \\
\text { given RPM for main engine; }\end{array}$ \\
\hline EDG & $\begin{array}{l}\text { The certified } \mathrm{NO}_{\mathrm{X}} \text { emissions per } \mathrm{KWh} \text { for } \\
\text { given power for diesel generator; }\end{array}$ \\
\hline $\mathrm{FC}$ & Fuel consumption; \\
\hline $\mathrm{C}_{\mathrm{i}}$ & The mass of consumed fuel $j$ at voyage $i$; \\
\hline & The diesel generators' operating hours; \\
\hline HME & The main engine's operating hours; \\
\hline
\end{tabular}

${ }^{1}$ Lecturer, Naval Architecture and Marine Engineering Department, Faculty of Engineering, Port Said University, Port Said, Egypt, E-mail: waleed.yehia@gmail.com

${ }^{2}$ Professor, Naval Architecture and Marine Engineering Department, Faculty of Engineering, Port Said University, Port Said, Egypt, E-mail: kamar_laila@hotmail.com

${ }^{3}$ Design Section, Canal Naval Construction Co., Customs Gate No. 57, Port Fouad, Port Said, Egypt, E-mail: hananibrahim62@yahoo.com

${ }^{4}$ Assoc.Professor, Naval Architecture and Marine Engineering Department, Faculty of Engineering, Port Said University, Port Said, Egypt, E-mail: moustafa3875@eng.psu.edu.eg

DOI: $10.21608 /$ pserj.2020.41525.1058

$\begin{array}{ll}\mathrm{i} & \text { The voyage number; } \\ \mathrm{j} & \text { The fuel type; } \\ \mathrm{m}_{\text {cargo }} & \text { Cargo carried (tons); } \\ \mathrm{NO}_{\mathrm{X}} & \text { Nitrogen oxides; } \\ \mathrm{P}_{\mathrm{DG}} & \text { The diesel generators' average power; } \\ \mathrm{P}_{\mathrm{ME}} & \text { The main engine's power for average } \\ \mathrm{Sj} & \text { RPM during the voyage; } \\ & \text { The average sulfur content of each fuel } \\ \mathrm{SO}_{\mathrm{X}} & \text { consumed in percentage; }\end{array}$

\section{INTRODUCTION}

The international shipping is a major contributing source of both GHGs and non-GHGs through its emitting exhaust gases. The final report of the $4^{\text {th }}$ IMO greenhouse gas (GHG) study is released by the International Maritime Organization (IMO). Prepared by a global network of CE Delft-led organizations, including ICCT researchers, the study found that overall maritime GHG emissions increased by about 10 percent between 2012 and 2018 [1, 2].

The maritime shipping is at a cross-road continuously. In April 2018, IMO through the $72^{\text {nd }}$ session of the Marine Environment Protection Committee decided to implement a preliminary strategy to reduce marine greenhouse gas (GHG) emissions [3]. This action is considered as one of the most recent developments in the field of sustainable shipping. This also sets the mood for what could arise next.

This strategy is in resolution MEPC304(72), and covering the following items, amongst many others: (a) Its vision, (b) ambition levels, (c) guidelines, (d) a list of timelines for the short, medium and long term candidates' actions, and (e) many diverse items, including the follow-up acts and others. 
As for the extent of ambition, it has been highlighted two key goals:

(i) To curb global shipping emissions as soon as possible in order to minimize the overall GHG annual emissions 50 percent until 2050 relative to 2008 .

(ii) To limit $\mathrm{CO}_{2}$ emissions for each transport work by about 40 percent by 2030 on average, promoting effort in order to reach 70 percent by 2050 relative to 2008.

Amongst some of the candidate short-term measures are the ones to be decided and agreed over the period 20182023. One can consider and analyze the use of speed optimization and speed reduction as a measure, having regard to safety concerns, round trip distance and market distortion. Then such a measure would not impair the capability of shipping to reach remote regions of the world. Rational basis for such measure is very clear and simple.

Based on the non-linear relationship among both ship speed and the consumed fuel (and therefore GHG ships' emissions, and so on), ship speed reduction seems to be a very promising solution. Thus, "ship speed reduction" comes more naturally as such an apparent candidate GHG emissions-reduction measure. Actually, it's not that easy. Some countries in Latin America (and most particularly Chile and Peru) opposed to using the expression "speed reduction" throughout the discussion at the IMO prior to MEPC 72. Consequently, although regulations that suggest compulsory speed limits with in the eyes of such countries (Chile and Peru), those limits are called "speed reduction" (and sometimes "slow steaming").

In a more literal way, ship speed reduction can be considered as (a) the voluntary option for any ship operator as a consequence of weakened trading conditions and / or the rising cost of fuel oil, or (b) The influence of certain other non-prescriptive measures, like the imposition on bunker charges [4]. These charges are protected by Market Based Measures (MBMs). MBMs were addressed at IMO over the period 2010-2013. However, this debate was halted for purely political concerns in 2013. See Psaraftis for a review of the debate [5, 6]. During April and May of 2019, meeting of the fifth Intersessional Working Group on Reduction of Ships' GHG emissions ( $5^{\text {th }}$ ISWG-GHG) and MEPC74 addressed the 14 approach methods for the reduction of GHG \& their Schedule. The $5^{\text {th }}$ meeting of ISWG-GHG set 14 approach methods and timeline frame for the introduction of the short-term actions in 2023. Approaching method No. 5 was entitled as: Develop a speed optimization and speed reduction mechanism [1].

It is now crystal clear, "Speed reduction has a beneficial role to play in reducing both ship resistance [7] and the emitted GHG, thereby improving ship's energy efficiency". This paper aims to asses and emphasizes the benefits of speed reduction throughout an application of this strategy on actual existing vessel with available ship energy efficiency management plan (SEEMP) data regulated incompliance with the amendments to MARPOL Annex VI concerning the information gathering framework for ships fuel oil consumption, implemented by resolution MEPC.278(70), which came into force on 1 March2018 [8].

\section{STATE OF THE ART}

Some previous literatures have been considered to use ship's speed to manage engines' fuel consumption and emitting exhaust gases from ships. Corbett et al. (2009) studied the efficiency and effect of speed reduction on worldwide shipping emissions [9]. Lindstad et al. (2011) explored the ability to minimize ship's $\mathrm{CO}_{2}$, GHGs and shipping costs while operating at reduced ship speeds [10]. Smith (2012) analyzed the effects and sensitivity of shipping speed and energy efficiency upon the gain of the ships' owners and the consequences for shipping's carbon emissions management [11]. Chang et al. (2013) addressed ship energy conservation for seagoing dry bulk carriers to evaluate ships' emissions when navigate with economical speed and then by-ships speeds reduction of $10 \%, 20 \%$ and $30 \%$ [12].

Also, Woo et al. (2014) analyzed the role of slow steaming on liner shipping's environmental efficiency and performance in terms of ship service speed, $\mathrm{CO}_{2}$ emissions and loop operating expenses [13]. Chang et al. (2014) also carefully analyzed and evaluated the influence of speed, which would minimize ships operation expenses and reduce the environmental impact of shipping [14]. Wider range of operational speeds has been captured and had a trend towards low speed (slow steaming). Johnson and Styhre had suggested lowering ship speed at sea by minimizing the harbors' unproductive waiting times (Johnson and Styhre, 2015). This is one of the ways in which ships' energy efficiency can be increased by reducing engine speed [15].

\section{ENERGY EFFICIENCY SPEED DEPENDENCY}

Operation of ships at lower speeds decreases their demand for power and therefore their fuel consumption. As a general guideline, a third-power feature relates power requirement to ship speed. This explains that a reduction in speed of 10 percent results in a reduction in shaft power requirements of about 27 percent. However, a ship navigating 10 percent slower will require around 11 percent additional time to cover the same cruising range. Considering this, a new thumb rule could be introduced claiming that there is a quadratic relationship between ship speed and the consumed fuel. Thus, a 10 percent reduction in ship speed will result in a 19 percent decrease in the consumed fuel [16].

Slow steaming may be described as trading voluntarily at a slower rate than the design speed of a vessel. Usually, this is seen in times of sluggish market conditions and/or high fuel costs. In times of depressed market conditions slow steaming can be supported by the fact that whatever fleet overcapacity existed was practically absorbed. In October 
2013, the total capacity of container vessels absorbed as a result of the longer round trip time for huge scale services reached TEU 1.27 million, based on estimates given by Alphaliner [17]. In 2016, UNCTAD [18] reported an ongoing sluggish demand threatened by a rapid massive worldwide growth of container supply, calculated at 8 percent in 2015 - its highest rate since 2010.

Nader R. Ammar [19], studied the cost-effectiveness and improvement Energy Efficiency Design Index (EEDI) for RO-RO cargo vessel by slow steaming and showed reduction of ship speed by $10 \%$ and $40 \%$ will reduce $\mathrm{CO}_{2}$ emission by $27.05 \%$ and $78.39 \%$ with cost-effectiveness of $121.2 \$ /$ ton $\mathrm{CO}_{2}$ and $287.6 \$$ ton $\mathrm{CO}_{2}$

In the early of 2018, Maersk and MSC, the owners of the largest container carriers, decided to further slowdown ships' speed to save expenses, with certain speeds as low as 13 knots [20]. Slow steaming is not only applied throughout the container market, however because of the higher speeds for such ships type it might seem to work much better there. Therefore, for every market slow steaming is registered. On a broad scale, and referring to the $3^{\text {rd }}$ IMO's GHG report, the decline in worldwide $\mathrm{CO}_{2}$ shipping emissions from 885 million tons in 2007 to 796 million tons in 2012 is mostly related to slow steaming owing to the shipping markets' extreme slump after 2008 [21].

\section{CALCULATION OF EEOI}

EEOI is an operational measure adopted by the International Maritime Organization (IMO) pursuant to MARPOL73/78, specifically Annex VI for the prevention of air pollution from ships. EEOI is the most widely used measure to assess ships' energy efficiency for every round trip, a year or a particular period of operations. As set out in MEPC. 1 / Circ. 684, the standard equation for EEOI may be used to calculate EEOI for a given period [9, 22].

$E E O I=\frac{\sum_{j} F C_{j} \cdot C_{F j}}{m_{\text {cargo }} \cdot D}$

In which the indicator is accessed on average for a period or for a number of round trips, the indicator may also be expressed as:

Average EEOI $=\frac{\sum_{i} \sum_{j} F C_{i j} \cdot C_{F j}}{\sum_{i} m_{\text {cargo }, i} \cdot D_{i}}$

Where, $i$ is the voyage number, $j$ is the fuel type, $\mathrm{FC}_{i j}$ is the mass of the consumed fuel oil $j$ at a certain voyage $i, \mathrm{C}_{\mathrm{F} j}$ is the ratio between the fuel mass and $\mathrm{CO}_{2}$ mass conversion factor for fuel $j, \mathrm{~m}_{\text {cargo }}$ is the transported cargoes (tons) or work done (TEU or passengers) or gross tons for ships carrying passengers and D is the distance in nautical miles corresponding to the cargo carried or the performed work.

EEOI is based entirely upon the ratio between the mass of the emitted $\mathrm{CO}_{2}$ and the unit of transport work. For a vessel, the detailed operational data is crucial to determining the EEOI value. EEOI unit will be calculated in the case of container ships or passenger ships by cargo carried (tons) and the work performed.

\section{SHIP EMISSION INDEX CALCULATIONS AND REPORTING}

The purpose of this section is to outline the calculation of ships emissions $\left(\mathrm{CO}_{2}, \mathrm{SO}_{2}\right.$ and $\left.\mathrm{NO}_{\mathrm{x}}\right)$ and review the guidance methodology of reporting these emissions to ship's administrations as per amendments to MARPOL Annex VI, Regulation 22A regarding a data collection scheme for ships' fuel oil consumption which was already implemented at MEPC70 on 28 October 2016 and took effect on 1 March 2018 (IMO Resolution MEPC.278(70)) [8].

\section{1. $\mathrm{CO}_{2}$ emission index}

$\mathrm{CO}_{2}$ index (identified lately as Energy Efficiency Operational Indicator) is described as the ships' $\mathrm{CO}_{2}$ efficiency with respect to the amount of emitted $\mathrm{CO}_{2}$ for each unit transport work as per Eq. (1). FC is the consumed fuel oil at sea as well as in port or for a round trip or period concerned by both main engines and auxiliaries, including boilers and combustion incinerators. Simply $\mathrm{CO}_{2}$ mass is announced relevant to FC by a conversion factors published by IMO. $\mathrm{C}_{\mathrm{F}}$ is a dimensionless conversion factor between both the consumed fuel and carbon dioxide $\left(\mathrm{CO}_{2}\right)$ emissions. It can also be measured in $\mathrm{g}$ based on carbon content. $\mathrm{C}_{\mathrm{F}}$ is tabulated as follows, see Table 1.

Table 1: Fuel mass to $\mathrm{CO}_{2}$ mass conversion factors $\left(\mathrm{C}_{\mathrm{F}}\right)$ (IMO, MEPC.1/Circ.684, 2009)

\begin{tabular}{|l|l|c|c|}
\hline \multicolumn{1}{|c|}{ Type of fuel } & \multicolumn{1}{|c|}{ Reference } & $\begin{array}{c}\text { Carbon } \\
\text { content }\end{array}$ & $\begin{array}{c}C_{F} \\
\left(\mathrm{t}-\mathrm{CO}_{2} / \mathrm{t}-\mathrm{Fuel}\right)\end{array}$ \\
\hline 1. Diesel/Gas Oil & ISO 8217 Grades DMX through DMC & 0.875 & 3.206000 \\
\hline 2. Light Fuel Oil (LFO) & ISO 8217 Grades RMA through RMD & 0.86 & 3.151040 \\
\hline $\begin{array}{l}\text { 3. Heavy Fuel Oil } \\
\text { (HFO) }\end{array}$ & ISO 8217 Grades RME through RMK & 0.85 & 3.114400 \\
\hline $\begin{array}{l}\text { 4. Liquified Petroleum } \\
\text { Gas (LPG) }\end{array}$ & $\begin{array}{l}\text { Propane } \\
\text { Butane }\end{array}$ & 0.819 & 3.000000 \\
\hline $\begin{array}{l}\text { 5. Liquified Natural Gas } \\
\text { (LNG) }\end{array}$ & & 0.827 & 3.030000 \\
\hline
\end{tabular}

Table 2: $\mathrm{CO}_{2}$ indicator reporting sheet (IMO, MEPC.1/Circ.684, 2009)

\begin{tabular}{|c|c|c|c|l|c|c|}
\hline \multicolumn{2}{|l|}{ NAME AND TYPE OF SHIP } \\
\hline $\begin{array}{c}\text { Voyage } \\
\text { or day } \\
\text { (i) }\end{array}$ & \multicolumn{2}{|c|}{ Fuel consumption (FC) at sea and in port in tonnes } & \multicolumn{2}{|c|}{$\begin{array}{c}\text { Voyage or time } \\
\text { period data }\end{array}$} \\
\cline { 2 - 7 } & $\begin{array}{c}\text { Fuel type } \\
(\quad)\end{array}$ & $\begin{array}{c}\text { Fuel type } \\
(~)\end{array}$ & $\begin{array}{c}\text { Fuel type } \\
(~)\end{array}$ & & $\begin{array}{c}\text { Cargo (m) } \\
\text { (tonnes or } \\
\text { units) }\end{array}$ & $\begin{array}{c}\text { Distance } \\
\text { (D) } \\
\text { (NM) }\end{array}$ \\
\hline 1 & & & & & & \\
\hline 2 & & & & & & \\
\hline 3 & & & & & & \\
\hline
\end{tabular}

Data on the consumed fuel oil / transported cargoes and distance travelled in a continuous sailing pattern could be gathered for a voyage or period of time, for example a day, as shown in the report sheet, see Table 2.

\subsection{Ship's SOx intensity (SOxI)}

$\mathrm{SO}_{\mathrm{X}}$ intensity is described as the amount of $\mathrm{SO}_{\mathrm{X}}$ that the vessel produces when transporting one tone of weight per unit of distance travelled. The primary selected data sources 
may be the log-book for the ship (log-book for bridge, logbook for engine, bunker delivery note and many other official documents). Shipping data collection encompasses distance travelled (nautical miles), consumed fuel in metric tons and its sulfur content (\%), transported cargoes (metric tons) and the distance in nautical miles corresponding to the cargo carried. For a voyage, $\mathrm{SO}_{\mathrm{X}}$ may be outlined as follows [23]:

$S O_{X} I=10^{6} \cdot \frac{\sum_{i} \sum_{j} F C_{j} \cdot S_{j}}{\sum_{i}\left(m_{\text {cargo }} \cdot D\right)}$

Where, $\mathrm{S}_{j}$ is the average sulfur content of each fuel consumed in percentage.

\subsection{Ship's NOx intensity (NOxI)}

$\mathrm{NO}_{X}$ intensity is described as the amount of $\mathrm{NO}_{\mathrm{X}}$ that the vessel produces when transporting one tone of weight per unit of distance travelled. The primary selected data sources may be the log-book for the ship (log-book for bridge, logbook for engine, log-book for deck, technical file for engine and many other official documents).

Shipping data collection encompasses distance travelled (nautical miles), consumed fuel (metric tons), transported cargoes (metric tons), operating time of both the main engines and diesel generators (hours), the average power of both the main engine and diesel generator $(\mathrm{kW})$ and main engine and diesel generators certified $\mathrm{NO}_{\mathrm{X}}$ emissions for corresponding power / rpm. For a voyage, $\mathrm{NO}_{\mathrm{X}}$ may be outlined as [23]:

$N O_{X} I=10^{6} \cdot \frac{\sum_{i}\left(H_{M E} \cdot P_{M E} \cdot E_{M E}\right)+\sum_{j}\left(H_{D G j} \cdot P_{D G j} \cdot E_{D G j}\right)}{\sum_{i}\left(m_{\text {cargo }} \cdot D\right)}$

Where, $\mathrm{H}_{\mathrm{ME}}$ is the operating times of the main engine in hours, $\mathrm{H}_{\mathrm{DG}}$ is the operating times of diesel generators in hours, $\mathrm{P}_{\mathrm{ME}}$ is the power of main engine for average RPM during the voyage, $\mathrm{P}_{\mathrm{DG}}$ is the diesel generators' average power, $E_{M E}$ is the certified $\mathrm{NO}_{\mathrm{X}}$ emissions per $\mathrm{kWh}$ for given RPM for main engine and $E_{D G}$ is the certified $\mathrm{NO}_{\mathrm{X}}$ emissions per $\mathrm{kWh}$ for given power for marine diesel generator.

\section{CASE STUDY}

M/V SERRANO is a 700 TEU 8350 DWT container ship selected as a target ship for this study in order to assess the outcomes of speed management and its role in improving EEOI. Fig. 1 and Table 3 describe the general arrangements and specification parameters of the selected ship "M/V SERRANO".

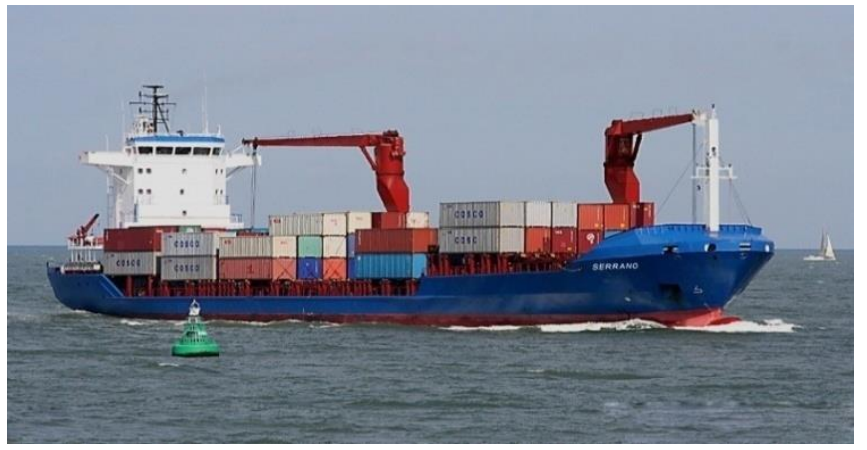

Figure 1: M/V SERRANO 700 TEU, 8350 DWT

Table 3: Specification parameters of M/V SERRANO

\begin{tabular}{|c|c|}
\hline Category & Parameters \\
\hline Name & SERRANO \\
\hline IMO No. & 9167083 \\
\hline Type & Container Ship \\
\hline Deadweight & 8,350 tons \\
\hline GRT/NRT & $6,393 / 3,278$ \\
\hline $\begin{array}{l}\text { Speed Recorded } \\
\text { (Max/Average) }\end{array}$ & $14 / 12.5$ knots \\
\hline Length $x$ Breadth $x$ Depth & $125.54 \times 19.40 \times 9.45 \mathrm{~m}$ \\
\hline $\begin{array}{l}\text { Type/Model/Power of Main } \\
\text { Engine }\end{array}$ & $\begin{array}{c}\text { Wartisila } 9138-5940 \\
\text { kw@ } 600 \text { rpm } \\
\end{array}$ \\
\hline M/E Fuel oil type & HFO $180 \mathrm{CST}$ \\
\hline $\begin{array}{l}\text { Type/ Model/Power of Aux. } \\
\text { Engine }\end{array}$ & $\begin{array}{c}\text { 2x Caterpillar3406-345 } \\
\text { Kw@1800 rpm }\end{array}$ \\
\hline
\end{tabular}

\subsection{Calculations of EEOI}

Within the study case, the candidate ship is subjected to calculations and analysis of EEOI during three consecutive years; 2017, 2018, and 2019 of normal operation. These data have been extracted from vessel SEEMP Part II for those consecutive years as guided in (MEPC.1/Circ.684, 2009).

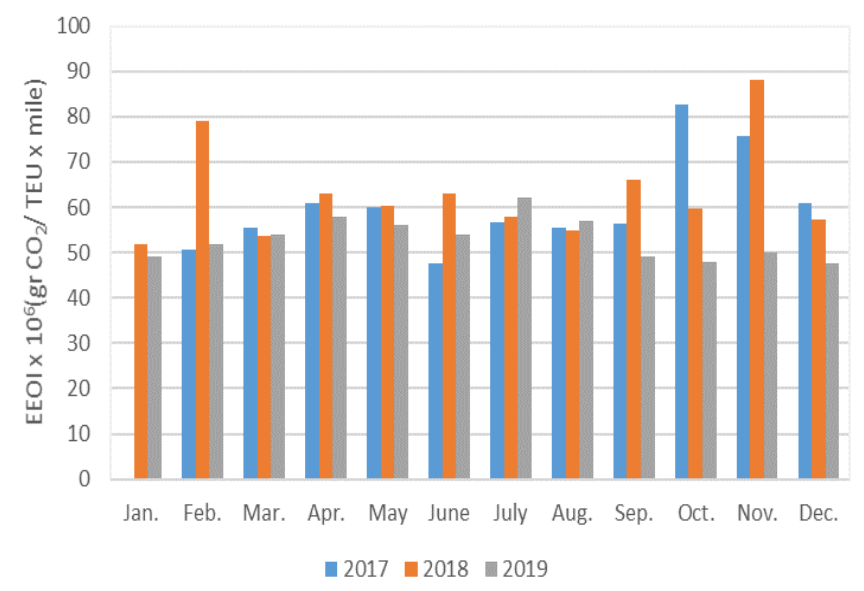

Figure 2: M/V SERRANO 700 TEU, 8350 DWT calculated EEOI 
Monthly average EEOI have been calculated as per Eq. 2 and plotted in Fig. 2 which shows EEOI of each month of the whole three years. Data of January, 2017 didn't consider in this analysis due to vessel off hire/ out of service due to scheduled dry docking.

\subsection{Speed management effect on EEOI}

Throughout Fig. 2, EEOI is different at each month. The value of EEOI depends upon on evaluation of cargo carried out or work performed, e.g. tons of $\mathrm{CO}_{2} /$ (tons . nautical miles), tons $\mathrm{CO}_{2}$ /(TEU. nautical miles) or tons $\mathrm{CO}_{2}$.

Among these parameters is vessel speed, in this study vessel recorded speed profile varies from 12to $14.5 \mathrm{kn}$. Considering that vessel average minimum, maximum speeds are these speeds, this wide range of speed profile have been captured and reassessed toward speed lowering strategy for the purpose of studying the effect of speed management on EEOI.

Four main speeds have been selected for this ship with reference to its speed profile, $12,13,13.5$, and 14.5 knots. These speeds are equivalent to reductions of $0 \%, 7 \%, 10 \%$, and $17 \%$ considering that 14.5 knots is the maximum average vessel speed.

Reassessment of EEOI granted by filtering voyages of the selected ship speeds and calculation of the average EEOI for these speeds for of each year are carried out. The overview of data comparison is concluded in Fig. 3 which shows the effectiveness of speed lowering that caused EEOI improvement by $35.6 \%$ while ship service speed reduced by $17 \%$.

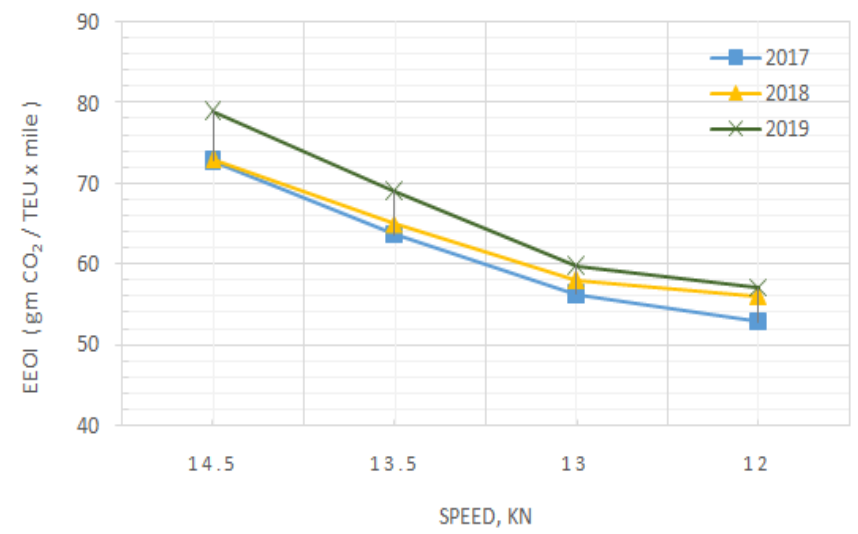

Figure 3: Overview of EEOI data comparison for reduced speed

\subsection{Analysis of NOxI emissions}

By implementing the same scenario of data analysis for $\mathrm{NO}_{\mathrm{X}} \mathrm{I}$ emissions, Fig. 4 summaries the result of the three years of operation and Fig. 5 points up the effect of speed reduction on $\mathrm{NO}_{\mathrm{X}} \mathrm{I}$ emissions, showing a reduction approaching $41.5 \%$ at $17 \%$ speed reduction.

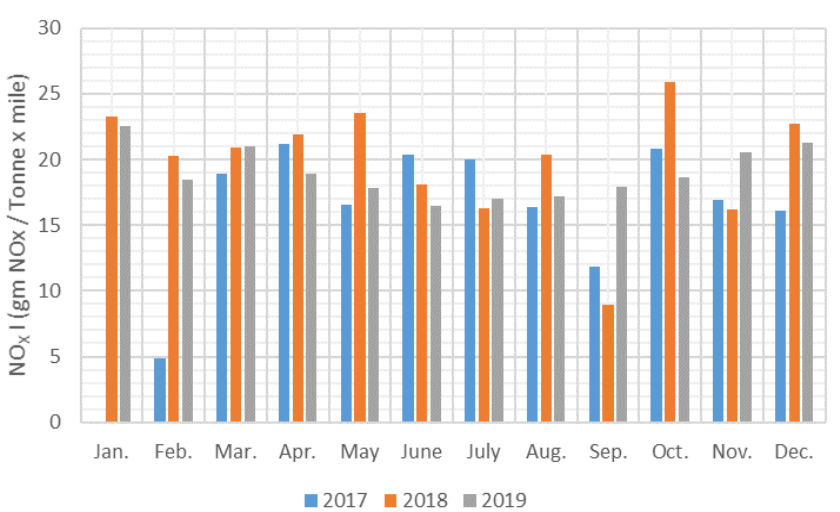

Figure 4: Summarized NOx emissions

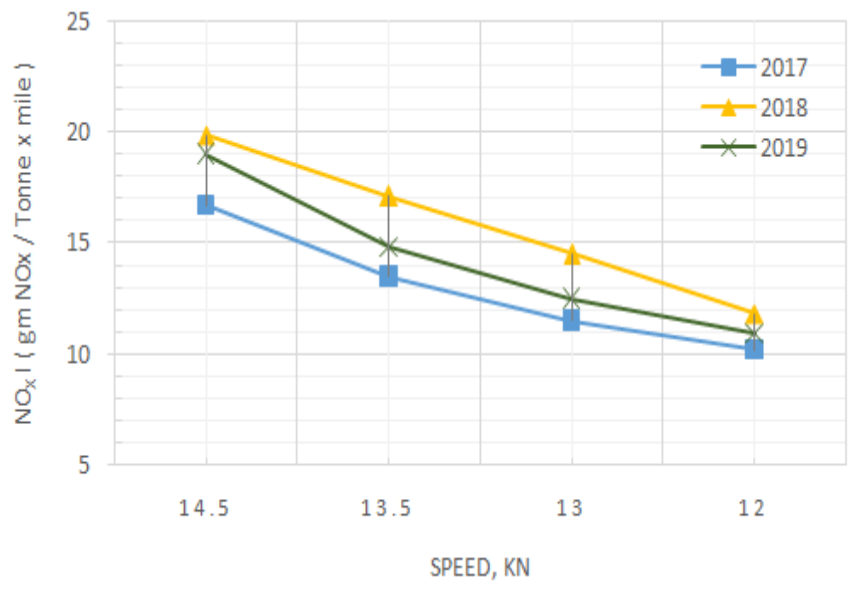

Figure 5: Overview of NOx emission comparison for reduced speed

\subsection{Sulfur cap 2020 and comparable study of SOxI emissions}

A new global limit on sulfur content in marine fuels called "IMO 2020" took effect by IMO on 1 January 2020 . The new regulation stipulates global maximum sulfur content in marine fuels of $0.5 \%$ (from $3.50 \%$ ). Therefore, for all ships operating outside certain designated emission control areas (ECA), where the limit is $0.10 \%$ already, the reduced limit is compulsory (Regulation 14 of MARPOL Annex VI) with effect from $1^{\text {st }}$ January 2020 , has been adopted at the $70^{\text {th }}$ session of MEPC on $28^{\text {th }}$ October 2016 via Resolution MEPC.280(70) [8].

In this section statistical analysis has been carried out for the three consecutive years of operation of the test case and shown in Fig. 6. The effect of speed reduction also studied; Fig. 7 shows a reduction of $21.7 \%$ for $\mathrm{SO}_{\mathrm{X}} \mathrm{I}$ at the selected speed profile with a reduction factor of $17 \%$ at 12 knots. Fig. 8 describes a comparison study for the implementation of "IMO 2020" regulation for limiting sulfur content of ship's fuel oil to $0.50 \%$. This study emphasizes and achieved a gain of $67.6 \%$ reduction in $\mathrm{SO}_{\mathrm{X}} \mathrm{I}$ while complying with previously mentioned regulation and the use of Low Sulfur Fuel Oil (LSFO) instead of High Sulfur Fuel Oil (HSFO). 


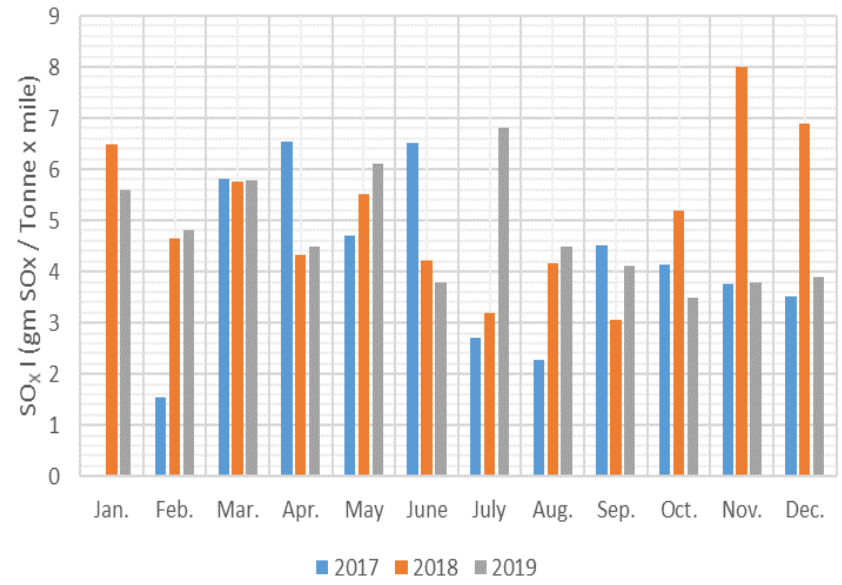

Figure 6: Summarized SOxI emissions

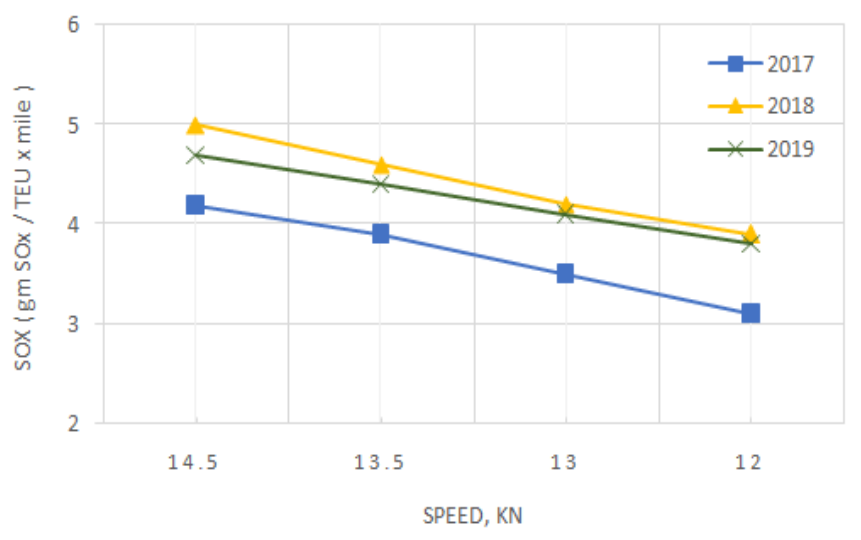

Figure 7: Overview of SOxI emission comparison for reduced speed

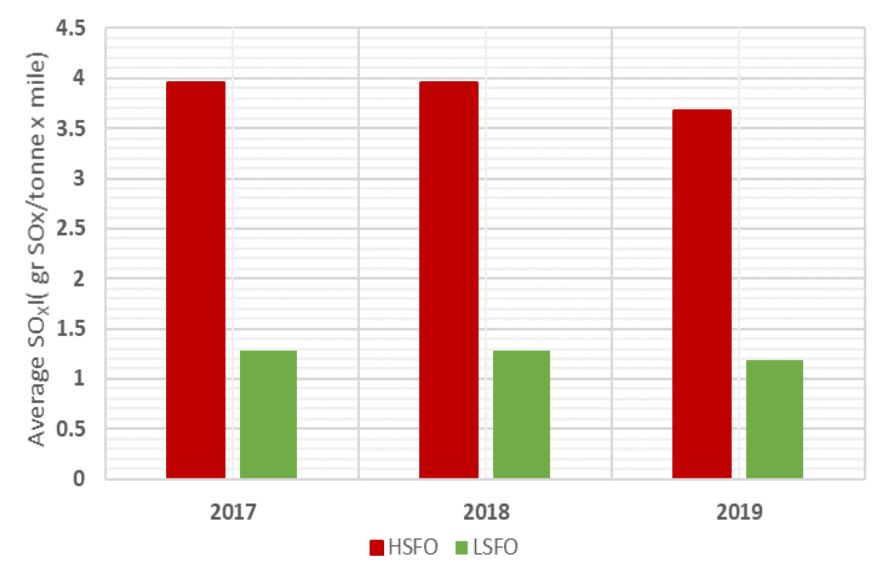

Figure 8: SOxI emission comparison between HSFO and LSFO

\section{CONCLUSION}

The objective of the study was improvement of energy efficiency for container ships as part of implementation of speed management with good practice developed in ship's EEOI and emissions.
The main conclusion drawn from the result of the study is the beneficial reduction of GHG emission indexes and improved $\mathrm{CO}_{2}$ footprint addressed by lowered EEOI while vessel operated at reduced speeds. It would also be worth exploring the applicability of operational measures for optimizing the energy efficiency to a real case with actual operating data for the purpose of validation and evaluation.

$\mathrm{CO}_{2}, \mathrm{SO}_{\mathrm{x}}$, and $\mathrm{NO}_{\mathrm{x}}$ emissions are considered as the main components of ship's emissions. The subject container ship has been examined according the strategy of reduced / managed speed. The calculation outcomes indicated significant reduction of $\mathrm{SO}_{\mathrm{x}}$ and $\mathrm{NO}_{\mathrm{x}}$ up to $21.7 \%$, and $41.5 \%$ respectively while vessel speed reduced by $17 \%$. The vessel EEOI improved by $35.6 \%$ at the same speed profile. Moreover, the practical application of Turning to (IMO 2020) global sulfur cap issued by IMO (MEPC.1/Circ.878) showed a reduction of $67.6 \%$ in $\mathrm{SO}_{\mathrm{X}} \mathrm{I}$ for the candidate test case.

The goal of this article is identified that a minor to moderate reduction of container ship speed is an effective issue. It brings the benefit to marine environment with lower GHG, and to ship's owners with ensured economic operation as a result of lowered fuel consumption.

Finally, this research shared a real ship fuel oil consumption data and reflects a valuable gain for its operational profile by only speed management. Possible extensions of these studies for different categories of vessels types and different operational profiles may be continue and begin a rational for ship's owners/managers for economic operation of their ships.

\section{Credit Authorship Contribution Statement}

W. Yehia: Conceptualization, Methodology, Formal analysis, Writing original draft, Supervision. M. M. Moustafa: Conceptualization, Methodology, Writingreview \& editing, Supervision. H. I. Mosaad: Writing original draft. L. B. Kamar: Supervision.

\section{Declaration of Competing Interest}

The authors state they have no idea of conflicting financial interests or personal relationships that may affect the work presented in this article.

\section{References}

[1] IMO (MEPC74). 2019a. MEPC 74-WP.6 - Report of the fifth meeting of the Intercessional Working Group on Reduction of GHG emission.

[2] Joung, T., Kang, S., Lee, J. And Ahn, J. (2020),"The IMO initial strategy for reducing Greenhouse Gas(GHG) emissions, and its follow-up actions towards 2050", Journal of International Maritime Safety, Environmental Affairs, and Shipping, Vol. 4, 2020. DOI: $10.1080 / 25725084.2019 .1707938$

[3] IMO Proposal to Include Work on Market-based Measures in the Programme of Follow-up Actions of 
the Initial IMO GHG Strategy, Submitted by France to the $4^{\text {th }}$ Intersessional Working Group on GHGs, IMO doc. ISWG-GHG 4/2/11; IMO: London, UK, 2018.

[4] Psaraftis, H. N. (2019), "Speed Optimization vs Speed Reduction: the Choice between Speed Limits and a Bunker Levy", Sustainability 2019, 11, 2249. DOI: 10.3390/su11082249

[5] Psaraftis, H. N. (2012), "Market Based Measures for Green House Gas Emissions from Ships: a Review", World Maritime University. Journal of Maritime Affairs, Vol. 11, 211-232.

https://doi.org/10.1007/s13437-012-0030-5

[6] Psaraftis, H. N. (2016), “Green Maritime Transportation: Market Based Measures: In Green Transportation Logistics: the quest for Win-Win Solutions", Ed. 1, Springer International Publishing, Switzerland, 2016.

[7] M. M. Moustafa, W. Yehia \& A. W. Hussein (2015), Energy Efficient Operation of Bulk Carriers by Trim Optimization, $18^{\text {th }}$ International Conference on Ships and Shipping Research, Lecco, Italy, 2015.

[8] IMO Resolution MEPC.213(63) Adopted on 2 March 2012, "Guidelines for the Development of a Ship Energy Efficiency Management Plan (SEEMP)", IMO doc MEPC 63/23 Annex 9; IMO: London, UK, 2012.

[9] Corbett, J. J., Wang, H. and Winebrake, J. J. (2009), "The effectiveness and costs of speed reductions on emissions from international shipping", Transportation Research Part D, Vol. 14,593-598. https://doi.org/10.1016/j.trd.2009.08.005

[10] Lindstad, H., Asbjørnslett, B. E. and Strømman, A. H. (2011), "Reductions in greenhouse gas emissions and cost by shipping at lower speeds", Energy Policy Journal, Vol. 39, 3456-3464, 2011. https://doi.org/10.1016/j.enpol.2011.03.044

[11] Smith, T. W. P. (2012), "Technical energy efficiency, its interaction with optimal operating speeds and the implications for the management of shipping's carbon emissions", Carbon Manage., Vol. 3:6, 589600.

[12] Chang, C. C. and Chang C. H. (2013), "Energy conservation for international dry bulk carriers via vessel speed reduction", Energy Policy, Vol. 59, 710-715.

[13] Woo, J. K. and Moon, D. S. (2014), "The effects of slow steaming on the environmental performance in liner shipping", Marit. Policy Manage., Vol. 41:2, 176-191.

[14] Chang, C. C. and Wang, C. (2014), "Evaluating the effects of speed reduce for shipping costs and $\mathrm{CO}_{2}$ emission", Transportation Research Journal, Part D Transport and Environment, Vol. 31, 110-115. https://doi.org/10.1016/j.trd.2014.05.020
[15] Johnson, H. and Styhre, L. (2015), "Increased energy efficiency in short sea shipping through decreased time in port", Transportation Research Journal, Part A: Policy and Practice, Vol. 71, 167-178. https://doi.org/10.1016/j.tra.2014.11.008

[16] Marantis, D. S. (2012), "Diploma Thesis: Improvement of Energy Efficiency of existing ships by performing \& evaluating Energy Audits onboard", National Technical University of Athens, 2012.

[17] Alphaliner (2013), "Extra and Super Slow Steaming Help Absorb $7.4 \%$ of Fleet. Alphaliner Weekly Newsletter", 2013. www.alphaliner.com

[18] UNCTAD (2016), Review of Maritime Transport 2016; United Nations Conference on Trade and Development; United Nations: New York, NY, USA; Geneva, Switzerland, 2016.

[19] Ammar, Nader R, (2018), "Energy- and costefficiency analysis of greenhouse gas emission reduction using slow steaming of ships: case study RO-RO cargo vessel", Ships and Offshore Structures Journal, Volume 13, - Issue 8

[20] Gkonis, K. G. And Psaraftis, H. N. (2012), "Modelling Tankers' Optimal Speed and Emissions", Archival Paper, SNAME Transactions. In Proceedings of the Annual Meeting of the Society of Naval Architects and Marine Engineers, Providence, RI, USA, 24-26 October 2012; Vol. 120, 90-115.

[21] Smith, T. W. P., Jalkanen, J. P., Anderson, B. A., Corbett, J., Faber, J., Hanayama, S., O'Keeffe, E., Parker, S., Johansson, L., Aldous, L., Raucci, C., Traut, M., Ettinger, S., Nelissen, D., Lee, D. S., Ng, S., Agrawal, A., Winebrake, J. J., Hoen, M., Chesworth, S., Pandey, A. (2014), “ Third IMO GHG study 2014", International Maritime Organization (IMO), London, UK.

[22] IMO MEPC 1/Circ.684, "Guidelines for Voluntary Use of The Ship Energy Efficiency Operational Indicator (EEOI)", London, UK, 2009.

[23] Kontovas, C. A. \& Psaraftis, H. N. (2009), “An Online Ship Emissions Calculator as a DecisionMaking Aid and Policy Evaluation Tool", 13 ${ }^{\text {th }}$ Congress of Intl. Maritime Assoc. of Mediterranean IMAM 2009, Istanbul, Turkey, 12-15 Oct. 2009. 